\section{Neutron Physics}

Proceedings of the Symposium held at Rensselaer Polytechnic Institute, May 5-6, 1961. Edited by M. L. Yeater. (Nuclear Science and Technology, a Series of Monographs and Textbooks. Vol. 2.) Pp. xiii +303. (New York and London: Academic Press, Inc., 1962.) $86 s$.

HIS volume reports the Proceedings of the Symposium held at the Rensselaer Polytechnic Institute in May, 1961, to mark the opening of the Neutron Physies Laboratory and its high-intensity linear electron accelerator. The papers presented cover all areas of neutron physics work, including nuclear physies measurements on fissile and non-fissile nuclei, solid and liquid state research and neutron thermalization problems. In addition, there is one paper on the fusion problem. Unfortunately, with such a wide range to cover, some limitations are inevitable. In effect this book presents a review of the resonance region neutron cross-section field and the thermalization field, while the other subjects are only covered in part. But, as a review of the cross-section field, it is marred by the very fact that it is a compilation of papers which present the results obtained in individual laboratories with individual machines, rather than broad surveys. Thus, while this book is quite useful in giving a picture of these fields to a 'new-comer', it is unable to compete with the text-books on neutron physies which are being published by the same publisher.

The style is informal in that the papers were prepared from tape recordings taken at the meeting, and the articles read as though they were being spoken rather than prepared in the manner of a text-book. This fact, coupled with the good layout of the book, makes it very easy to read. On the whole this is an interesting and useful book but one likely to have a rather short life.

\section{P. A. Egelstaff}

\section{Brompton Hospital Reports}

Vol. 30, 1961. (A Collection of Papers by Members of the Staffs of the Hospitals for Diseases of the Chest (Brompton Hospital; London Chest Hospital); and of the Institute of Diseases of the Chest.) Pp. viii +287 . (London: LloydLuke (Medical Books), Ltd., 1962.) 15s. net.

GOR many years papers published by the staffs of the Brompton Hospital, London Chest Hospital and the Institute of Diseases of the Chest have been brought together in a composite volume which is issued annually. The thirtieth of these is notable for an article by Sir Russell Brock on the surgical treatment of pulmonary stenosis and a series of articles dealing with various aspects of sarcoidonis. There is also a description of a quantitative method of studying tumour cells in blood by Drs. S. W. A. Kuper, J. R. Bignall and E. D. Luckeock as well as an assessment of antitussive drugs in man by Dr. F. J. Prime. Dr. Lynne Reid examines the relationship between chronic bronchitis and the hypersecretion of mucus, while Dr. J. H. Ross reviews the surgery of the thoracic duct. In the main the articles are written in 'popular' style and are well supported by diagrams and photographs.

T. H. HAWKINS

\section{The Exploration of Outer Space}

By Sir Bernard Lovell. Pp. ix +87 . (London: Oxford University Press, 1962.) $16 s$.

THIS is an introduction for the layman to some of the recent developments in astronomy, particularly those involving radio methods of investigation. Sir Bernard's skill in popular exposition is well known, and this book bears out his reputation.

It is based on the Gregynog Lectures, given in Aberystwyth in October 1961, and starts with a chapter on techniques followed by further chapters on the solar system, the structure of galaxies and the origin and evolution of the universe. With all this in 87 octavo pages there is obviously no room for details but most of the problems at present engaging attention in the field find at least a mention.

The final chapter is on extra-terrestrial life and the possibility of detecting it. The author gives a strong warning about the danger that the U.S.S.R. or the United States might inadvertently contaminate other planets with organisms from the Earth and perhaps destroy our chance of studying their own life-forms, if any. This warning comes over with particular force when it is remembered that Sir Bernard's criticisms of high-altitude nuclear explosions were 'pooh-poohed' by 'responsible' scientists before the event of July 9,1962 , but are now seen to have been largely justified. The last chapter also describes the recent attempts to receive $21-\mathrm{cm}$ radio waves from intelligent beings on nearby stars. It is ironical that these attempts have already been overtaken by scientific progress, for coherent light from lasers is now considered to be a more effective method of communication over interstellar distances and who can say what will be the best technique available in even ten, let alone a hundred or a thousand, years' time?

J. R. SHAKESHAFT

The Annual of the British School at Athens, No. 56, 1961

Pp. $x+228+31$ plates. (London: The British School at Athens, 1962.) 105s. net.

$T$ HE 1961 Annual maintains the British School's high standard of archæological publication. The weight of this volume is given to two subjects, topography and epigraphy; but numismatics, excavation publication and early Athenian history are also treated and there is an article about ancient Greek kilns and their "double stoking tunnel".

D. M. Metcalf discusses the Byzantine scyphate (saucershaped) bronze coins in Greece during the twelfth and early thirteenth centuries. From a study of hoards and sitefinds he assigns certain types to areas and suggests possible mints. M. F. S. Hood and J. Boardman publish three early Iron Age tombs at Knossos, Crete; mainland Greece is represented by the publication of evidence for Mycenæan occupation near the Cyclopean Terrace Building at Mycenæ and by two pieces of a chariot larnax from the same site. Prof. Hopper's article on the early history of Athens destroys the thesis that there was a connexion between the three 'regions' of ancient Athens (Plain, Shore, Hill) and political parties later imagined to have been based on them. The author attempts to reconstruct Athenian history in the seventh and sixth centuries B.c. and sees political parties as fluctuating groups supporting particular individuals who were mostly concerned with advancing their own political interests. Thus he expresses a view of ancient Athenian politics coming increasingly to the fore, displacing the accepted idea (based on modern and political theory) of 'conservatives', 'moderates' 'radicals'.

The emphasis on topographical research is a marked feature of Greek archæology to-day. The famous sites are for the most part dug and published and so the topographers have taken the field and are doing valuable work in establishing the relations of small outlying sites to main centres, in working out the chronological patterns of settlement in specific areas and in identifying sites for which literary evidence exists. In this volume Helen Waterhouse and R. Hope Simpson present (at perhaps excessive length) the second part of their exploration of prehistoric Laconia, J. M. Cook argues for identifying four small classical cities near ancient Miletus in Turkey, and Garnett and Boardman publish the results of underwater reconnaissance off the island of Chios in 1954 .

For epigraphy, A. Schachter publishes ten small inscriptions from Boeotia and Ursula Duncan writes on lettering by Attic masons. T. B. Mitford gives the formal publication of the 113 Hellenistic inscriptions from Old Paphos in Cyprus. Twenty-one of these are new, and two are important.
Peter Warren 